頝動脈狭窄症に対する治療選択

一エビデンスからみた頝動脈ステント留置術の位置づけ，今後の展開について一

里見 淳一郎

きたじま田岡病院脳神経外科

\title{
Optimal Treatment for Carotid Artery Stenosis : Current Status and Future Perspective
}

\author{
Junichiro Satomi, M.D., Ph.D. \\ Department of Neurosurgery, Kitajima Taoka Hospital
}

The natural course of carotid artery stenosis is influenced by its symptomatology and stenosis ratio, both of which influence the choice of surgical interventions for moderate to severe stenotic lesions. The equivalence of carotid stenting and carotid endarterectomy rendered through refinement of therapeutic tools and practical technique ensured therapeutic efficacy with a concurrent reduction in morbidity and mortality. Recent advances in therapeutics and morphological assessment of plaques have resulted in the need for a revamp of surgical interventions for asymptomatic lesions. Moreover, clinical evidence related to optimal treatment for carotid artery stenosis should be updated to enable comparison of various treatment options.

(Received July 8, 2019; accepted July 31, 2019)

Key words : carotid artery stenosis, CAS, CEA

Jpn J Neurosurg（Tokyo）28:777-782, 2019

\section{はじめに}

䅡動脈狭窄症の自然予後を規定する因子として, 症候 性の有無，狭窄率は最も重要な因子であり，無症候性高 度狭寉，症候性中等度狭窄において，内科治療に対する 頝動脈内膜剝離術（carotid endarterectomy：CEA）の有 効性が示されて 20 年が経過する。近年のプラーク性状 診断，内科治療の進歩は目覚ましいものがあり，これら の因子を考慮した新たなエビデンスの創出が望まれてい る. 頝動脈ステント留置術 (carotid artery stenting: CAS) は, CEA高危険群のみならず標準危険群に対しても CEA と同等の治療効果が得られることが示されているが，そ
れぞれの治療における合併症内訳が異なり, 特にCASに おける周術期脳卒中の発生，高歯者に対する成績不良が 今後克服すべき問題点として挙げられる。ささらに，CAS と内科治療を比較した試験はなく, 今後の検討課題であ る。本稿では, 頚動脈狭窄症に対する治療, 特に CAS を 中心にこれまでの治療エビデンスの概説および解釈，本 邦での現状を示し，今後の展開について言及する.

\section{これまでの頚動脈狭窄症治療のエビデンス}

\section{CEA vs. 内科治療（症候性病変）}

1991 年に報告された NASCET (North American Symp-

連絡先：里見淳一郎，テ 771-0204 板野郡北島町鯛浜字川久保 30-1 医療法人きたじま倚山会きたじま田岡病院脳神経外科 Address reprint requests to: Junichiro Satomi, M.D., Ph.D., Department of Neurosurgery, Medical Corporation Kitajima Izankai Kitajima Taoka Hospital, 30-1 Kawakubo, Tainohama, Kitajima-cho, Itano-gun, Tokushima, 771-0204, Japan 
tomatic Carotid Endarterectomy Trial $)^{23)}$ は, 北米の施設を 対象に中等度以上 $(>70 \%)$ の狭窄を有する症候性病変 における CEA と内科治療の有効性を比較した randomized controlled trial である. 2 年間の観察期間で病変側に 生じた脳卒中の発生率が, CEA 群が $9.0 \%$, 内科治療群 26.0\%であり，CEA 群が有意に低い結果であった。その 後, 5 年間のフォローアップにおいても, 病変側に生じ た脳卒中の発生率は CEA 群が $15.7 \%$, 内科治療群 $22.2 \%$ であり, CEA 群が有意に低い結果であったが, CEA の効 果は，中等度狭窄（50～69\%）に対しては限定的，女性 にはみられない結果であった ${ }^{22}$. 本試験のサブ解析で, 頚動脈狭窄症の自然歴として, 潰瘍性プラークの存 在 ${ }^{13)}$, 対側閉塞例 ${ }^{15)}$, 病変側頭蓋内血管狭窄合併例 ${ }^{19)}$ は 脳卒中発症率を高めるが，一方で偽性閉塞症例 ${ }^{14)}$ ，一過 性黒内障発症症例 ${ }^{2}$ では脳卒中発症率が低いことが明ら かとなった。

\section{CEA vs. 内科治療（無症候性病変）}

無症候性病変に対しては, 1995 年に報告された北米を 中心とした ACAS (Asymptomatic Carotid Atherosclerosis Study $)^{1)}$ において, $60 \%$ 以上の狭窄で CEA の 5 年間での 同側脳卒中ならびに周術期の重篤な合併症の発生率が CEA 群 $5.1 \%$, 内科治療群 $11.0 \%$ と CEA 群が有意に低 かった。周術期合併症は $2.3 \%$ あったため, 施設基準と して周術期合併症 $3 \%$ 未満を要求される結果となった. 9 年後の 2004 年に報告されたヨーロッパを中心とした ACST (Asymptomatic Carotid Surgery Trial) ${ }^{16)}$ において は, 内科治療の進歩（抗血小板療法, ス夕チン, 降圧) にもかかわらず, 頝動脈エコーで $60 \%$ 以上の狭窄におい て, 全脳卒中の発生率が CEA 群（割付後早期に CEA） 6.4\%, 内科治療群 (必要が生じれば CEA) $11.8 \%$ と CEA 群が有意に低かった。

これまでに示したエビデンスにおける内科治療は, 15 25年以上前に行われたものである. 近年の内科治療 の洗練化により, 䅡動脈狭窄症に対する内科治療の有効 性は拡大してきており，エビデンスの刷新が必要な時期 に差し掛かっている。

\section{CEA vs. CAS}

\section{CEA high risk に対する CAS}

CAS の CEA に対する有効性は, まず CEA 高危険群と の比較が検討された. SAPPHIRE study (Stenting and Angioplasty with Protection in Patients at High Risk for Endarterectomy study) ${ }^{32)}$ は，米国の多施設において,
CEA 高危険基準（重症心疾患, 重症肺疾患, 対側内頝動 脈閉塞, 対側喉頭神経麻痺, 頚部手術の既往, CEA 後再 狭窄，80歳以上）を少なくとも 1 つ満たす症例を対象と して行われ，30日以内の脳卒中/心筋梗塞/死亡は CAS 群 4.8\%, CEA 群 $9.8 \%$ と CAS 群で少ない傾向があり, primary endpoint (30 日以内の脳卒中/心筋梗塞/死亡およ び 1 年間の同側脳卒中/死亡） は CAS 群 $12.2 \%, \mathrm{CEA}$ 群 20.1\%と CAS の CEA に対する非劣性が証明された。本 研究の対象者は, 無症候性病変が約 70\%を占めており, 無症候性病変では CEA に比し CAS が有用であったが, 症候性病変では同等の primary endpoint であり差を認め なかった。

\section{CEA normal risk に対する CAS}

EVA-3S (Endarterectomy Versus Angioplasty in patients with Symptomatic Severe carotid Stenosis ${ }^{20)}$ は，フランス で症候性䅡動脈狭窄（中等度以上狭窄）に対して行われ た試験であり, 塞栓防御器材 (embolic protection device: EPD）は $92 \%$ に使用されていた。 Primary endpoint（治 療後 30 日以内の全脳卒中/死亡), secondary endpoint (1) 治療後 30 日以内の心筋梗塞, 一過性脳虚血発作, 脳神経 障害, 局所・全身合併症, (2)治療後 6 力月までの全脳卒 中/死亡）ともに有意差をもって CAS に多い結果（CAS 群 9.6\%, CEA 群 3.9\%）となり，CAS の CEA に対する 非劣性を示せなかった。

SPACE (Stent-supported Percutaneous Angioplasty of the Carotid arterey versus Endarterectomy) ${ }^{28)}$ は, ドイツ, オーストラリア，スイスで行われた症候性䅡動脈狭窄 (中等度以上狭窄) に対する試験であり, $\mathrm{EPD}$ の使用率 は27\%にとどまっていた. Primary endpoint（治療後 30 日以内の病変側脳卒中/死亡) では CAS 群 6.8\%, CEA 群 $6.3 \%$ とわずかの差であったが, CAS の CEA に対する非 劣性を示せなかった。

ICSS (International Carotid Stenting Study) ${ }^{18)}$ は, 欧州, オーストラリア, ニュージーランド, カナダにおいて症 候性頝動脈狭窄に対して行われた試験であり，EPD は $72 \%$ に使用されていた. Primary endpoint（治療後 30 日 以内, 120 日以内の脳梗塞/心筋梗塞/死亡）は, 120 日以 内の脳梗塞/死亡では CAS 群 4.0\%, CEA 群 3.2\% と有意 差はなかったが，心筋梗塞を加えると CAS 群 8.5\%, CEA 群 $5.2 \%$ と CAS 群に有意に多く, CAS の CEA に対

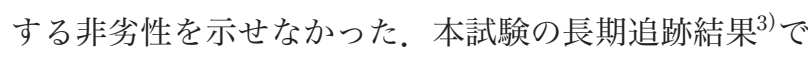
は, 5 年での重症脳梗塞は CAS 群 6.4\%, CEA 群 6.5\% と 有意差はなかったが, 全脳卒中は CAS 群 $15.2 \%$, CEA 群 9.4\%であり, 脳卒中のほとんどが軽症脳梗塞であった 
が，CAS 群のほうが有意に高かった。

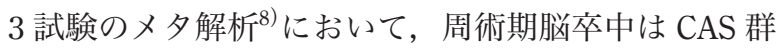
7.4\%, CEA 群 4.3\% と CAS 群に有意に多く, うち軽症脳 卒中が CAS 群 $3.9 \%$, CEA 群 $1.9 \%$ と CAS 群に多い結果 であった。また, 70 歳以上では 30 日以内の脳卒中/死亡 は CAS 群で $10.5 \%, \mathrm{CEA}$ 群で $4.1 \%$ と有意に高かった。

上記の 3 試験は, CAS における EPD の使用が義務づ けられておらず，また術者も厳格に選定されておらず， CAS自体のクオリティーが担保されていなかったことが 有用性を示せなかった主要因と考えられる。

CREST (Carotid Revascularization Endarterectomy vs. Stenting Trial ${ }^{5)}$ は, 北米で行われた試験であり, 症候性 病変 $(50 \%$ 以上の狭窄) ならびに無症候性病変 (70\%以 上の狭窄）症例を対象とし，EPD の使用を義務づけてい る. Primary endpoint (治療後 30 日以内の全脳卒中/心筋 梗塞/死亡, ならびに 4 年以内の同側脳卒中）はCAS 群 $7.2 \%, \mathrm{CEA}$ 群 $6.8 \%$ と有意差は認められなかった。症候 性, 無症候性に分類した検討では, CAS に primary endpoint到達が多い傾向はあったが, 両治療間の有意差は認 められなかった。 イベントごとの検討では, CAS 群に脳 梗塞（CAS 群 4.1\%, CEA 群 2.3\%), CEA 群に心筋梗塞 （CAS 群 1.1\%，CEA 群 2.3\%）が有意に多かった．周術 期を超えると, 両治療ともイベントの発生は低かった。 また，70 歳以下では CAS が，70 歳以上では CEA が好成 績であった。長期追跡結果 ${ }^{6)}$ では, 10 年での複合 endpoint (周術期脳卒中/心筋梗塞/死亡) で CAS 群 $11.8 \%$, $\mathrm{CEA}$ 群 $9.9 \%$ と有意差はなく, 同側脳卒中も CAS 群 $6.9 \%$, CEA 群 $5.6 \%$ と有意差はなかった。

ACT (Asymptomatic Carotid Trial）I ${ }^{24)}$ は米国で行われ た試験であり, 無症候性中等度狭窄（70\%以上）を対象 とし，EPDの使用を義務づけている. Primary endpoint (30 日以内の脳卒中/心筋梗塞/死亡および 1 年以内の病 側脳卒中）は CAS 群 $3.8 \%, \mathrm{CEA}$ 群 $3.4 \%$ であり, CAS の CEA に対する非劣性を示した。心筋梗塞を除いた 30 日以内の脳卒中/死亡においても CAS 群 $2.9 \%$, CEA 群 $1.7 \%$ と有意差を認めなかった. 5 年のフォローアップで のイベント発生率も両治療間で差を認めなかった。

CREST, ACT I は, 前述の 3 試験（EVA-3S, SPACE, ICSS）と異なり, 適格な術者に限定し EPD を含むデバ イスの使用を統一したこと, 転帰項目に心筋梗塞を加え たことが CAS のCEA に対する同等性, 非劣性の証明に つながったと考えられる。

2000 年以降の上記試験期間は, CEA のクオリティー はほぼ変わらないと推定される一方, CAS はデバイスの 改良過程, 特に EPD が日進月歩を遂げた時期であり, 年
を追うごとにCASの成績がよくなっている点 ${ }^{27)} も$ 注目 する必要がある。一方, CAS の問題点として, 高齿者で 成績が不良であること, 周術期血栓塞栓性合併症に起因 すると考えられる脳梗塞が多いことが浮き彫りとなった。

現在, 無症候性䅡動脈狭窄症に対する head-to-head comparison 試験として, 最良内科治療 (best medical treatment: BMT), CEA+BMT, CAS+BMT を比較する SPACE2 試験 ${ }^{10)}$, CREST 2 試験 ${ }^{17}, \mathrm{CEA}+\mathrm{BMT}, \mathrm{CAS}+$ BMT を比較するACST 2 試験7)がある. SPACE2 試験は, BMT のオプションを希望しない登録患者が多く, 規定 数に達しなかったため試験中止となり, 登録患者の追跡 のみ行うこととなった. CREST 2, ACST 2 試験は進行 中であり，それぞれ 2020 年, 2021 年に結果が公表され る予定である。

\section{本邦における頝動脈狭窄症治療の現状}

本邦における䅡動脈狭窄症治療の特徵として, CAS, CEA ともに $90 \%$ 以上の症例で脳神経外科医が施行して いる点が挙げられる。諸外国においては, CEA は血管外 科医, CAS は循環器内科医, 神経放射線科医が行ってき たのと異なり, 本邦では黎明期より脳神経外科が主体的 に両治療を発展させてきた歴史に基づくものと考元られ る. 頝動脈狭窄症に対する CAS, CEA の施行比率は, 米 国においてはCEAが $90 \%$ 前後を占めるのに対し, 本邦 では, 2004 年に CAS の件数が CEA を上回り, 以後増加 の一途を示し, 最近では全体の $2 / 3$ を CAS が占める状況 で推移している (Fig. 1). 本法での治療成績は, EPD シ ステムを含むデバイスの洗練化, 適正使用, 日本脳神経 血管内治療学会主導による術者の教育・養成の成果も相 まって，年を追うごとに向上しており，諸外国の成績を 凌駕する状況にある11)21)30).

CAS の問題点として, 抗血小板薬の使用継続が必要で あることが議論になるが, 前述のとおり, 周術期を超え た中長期期間においても血栓塞栓性合併症の比率に CAS, CEA 両治療で差は認めていない. CAS 自体は長期 の抗血小板薬 2 剂服用は必要ではなく, 数力月以降に単 剂に減量し継続することで問題はない. CEA施行患者も 全身血管病を有することが多く, 抗血小板薬を断薬でき る症例は少ない。

\section{今後の治療展開一dual-layer micromesh ステントの可能性一}

CAS の未解決の問題として, ステント留置時にメッ 


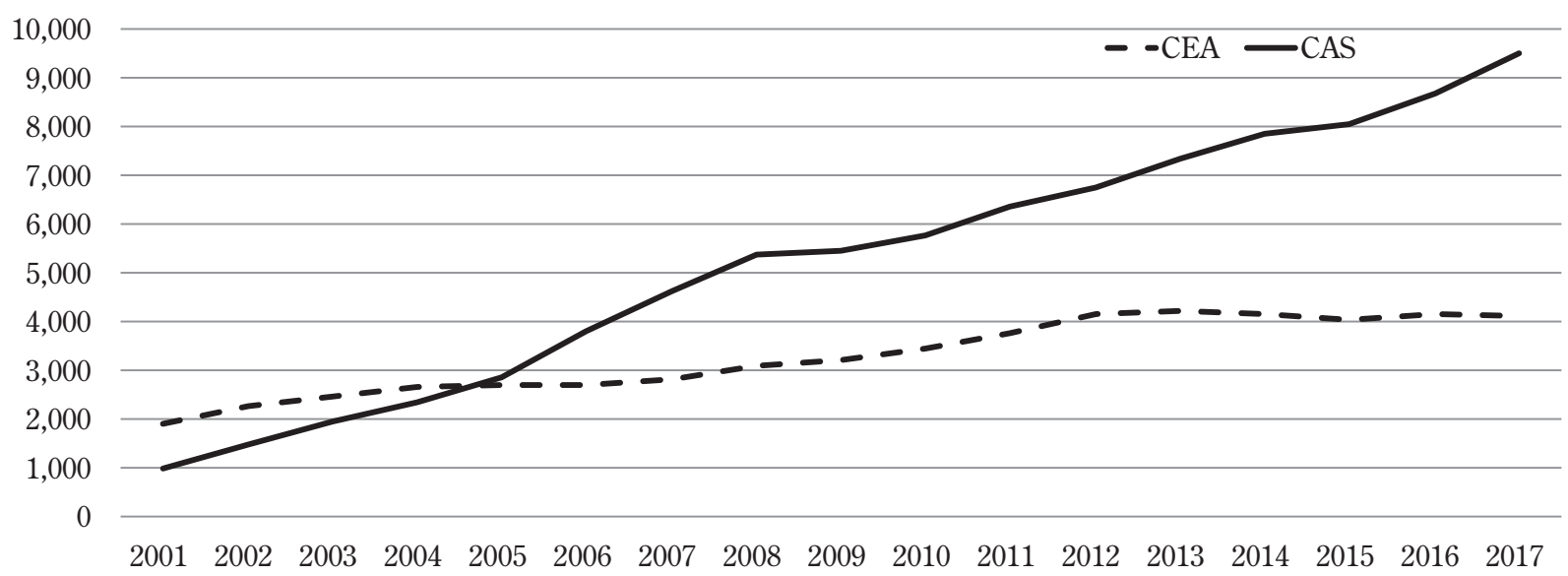

Fig. 1 Trends in the number of procedure of carotid revascularization

(Data from Annual Report of Japan Neurosurgical Society)

シュから圧搾飛散する微小プラークによる脳梗塞が挙げ られる。ステント形状の検討から, open-cell デザインに 比べ closed-cell デザインがよりプラークを被覆する点で 望ましいことが報告されている29)31).

屈曲病変への flexibility, conformability に優る opencell ステントを近位および遠位端に用い，中央部はプ ラークを被覆すべく closed-cell ステントをデザインした ハイブリッドステントの開発 ${ }^{922}$ (2) が進められたが，実 用には至っていない.

近年，血管壁への scaffolding 作用の強いナイチノール 層（外層）とプラーク被覆作用に強いマイクロメッシュ 層（内層）をもつ dual-layer micromesh ステントが開発 された，Roadsaver ステント ${ }^{4}$ (米国，本邦では CASPER ステント）は, 現在 Food and Drug Administration（FDA） の認可を受けた唯一の dual-layer micromesh ステントで あるが，2 層のナイチノールで構成され，内層のメッ シュは $0.381 \mathrm{~mm}^{2}$ のわめて小径のセルサイズとなって いる. Roadsaver ステントの効果を検証した CLEARROAD (Carotid triaL investigating the efficacy of Endovascular treatment of carotid ARterial disease with the multilayer ROADsaver stent） trial では，症候性病変が $31 \%$, EPD の使用は 58\%であった. Primary endpoint（30 日以 内の脳卒中/心筋梗塞/死亡) は $2.1 \%$ にどまっていた。

CGuard ステントは，内層を生体安定性の高い $20 \mu \mathrm{m}$ の polyethylene telephtalate で編んだメッシュ構造となっ ており，異物反応の軽減が期待されている。CARENET trial (CARotid Embolic protection using microNET) ${ }^{26)}$ で は，これまでのメッシュのないステントと比較し，治療 後の新規脳梗塞の出現が半減し, 梗塞体積が $1 / 10$ に
なったとしている.

Gore ステントは, 外層を $500 \mu \mathrm{m}$ の closed-cell ステン ト，内層にヘパリンコーティングを施した血液親和性の 高いメッシュ (Carmeda BioActive Surface Heparin Surface：CBAS）で構成されている. SCAFFOLD trial' ${ }^{25)}$ は, $\mathrm{CEA}$ 高危険群の中等度以上の頝動脈狭窄に対する Gore ステントの使用を 265 人で検証した試験であり, 30 日以 内の脳卒中/心筋梗塞/死亡は $3.0 \%, 30$ 日以内の脳卒中/ 死亡は $1.5 \%, 30$ 日以内の脳卒中は $1.1 \%$ と低いもので あった。

本邦においてもCASPER ステントを用いた国内治験 が開始されており，結果に期待が寄せられている.

\section{結 語}

䅡動脈狭窄症に対する治療は, 近年の治療の発展に従 いCEA，CAS，内科治療とも成績が向上してきている が，周術期塞栓性合併症を克服するデバイスの洗練化， 新規開発が進むCAS の治療成績に注目していく必要が ある。一方, 無症候性病変, 高齢者への治療介入は慎重 に検討しなければならず，各治療を比較した新たなエビ デンスの創出が必要な時期に差し掛かっている.

著者は日本脳神経外科学会への COI 自己申告の登録を完了 しています。本論文に関して開示すべき COI はありません.

\section{文 献}

1) Endarterectomy for asymptomatic carotid artery stenosis. Executive Committee for the Asymptomatic Carotid Ath- 
erosclerosis Study. JAMA 273: 1421-1428, 1995.

2) Benavente O, Eliasziw M, Streifler JY, Fox AJ, Barnett HJ, Meldrum H ; North American Symptomatic Carotid Endarterectomy Trial Collaborators: Prognosis after transient monocular blindness associated with carotid-artery stenosis. N Engl J Med 345 : 1084-1090, 2001.

3) Bonati LH, Dobson J, Featherstone RL, Ederle J, van der Worp HB, de Borst GJ, Mali WP, Beard JD, Cleveland T, Engelter ST, Lyrer PA, Ford GA, Dorman PJ, Brown MM ; International Carotid Stenting Study Investigators : Longterm outcomes after stenting versus endarterectomy for treatment of symptomatic carotid stenosis: the International Carotid Stenting Study (ICSS) randomised trial. Lancet $385:$ 529-538, 2015.

4) Bosiers M, Deloose K, Torsello G, Scheinert D, Maene L, Peeters P, Muller-Hulsbeck S, Sievert H, Langhoff R, Bosiers M, and Setacci C : The CLEAR-ROAD study : evaluation of a new dual layer micromesh stent system for the carotid artery. Euro Intervention 12: e671-676, 2016.

5) Brott TG, Hobson RW 2nd, Howard G, Roubin GS, Clark WM, Brooks W, Mackey A, Hill MD, Leimgruber PP, Sheffet AJ, Howard VJ, Moore WS, Voeks JH, Hopkins LN, Cutlip DE, Cohen DJ, Popma JJ, Ferguson RD, Cohen SN, Blackshear JL, Silver FL, Mohr JP, Lal BK, Meschia JF ; CREST Investigators : Stenting versus endarterectomy for treatment of carotid-artery stenosis. $N$ Engl J Med $363: 11^{-}$ 23, 2010.

6) Brott TG, Howard G, Roubin GS, Meschia JF, Mackey A, Brooks W, Moore WS, Hill MD, Mantese VA, Clark WM, Timaran CH, Heck D, Leimgruber PP, Sheffet AJ, Howard VJ, Chaturvedi S, Lal BK, Voeks JH, Hobson RW 2nd; CREST Investigators : Long-Term Results of Stenting versus Endarterectomy for Carotid-Artery Stenosis. $N$ Engl J Med 374: 1021-1031, 2016.

7) Bulbulia R, Halliday A : The Asymptomatic Carotid Surgery Trial-2 (ACST-2) : an ongoing randomised controlled trial comparing carotid endarterectomy with carotid artery stenting to prevent stroke. Health Technol Assess 21:1-40, 2017.

8) Carotid Stenting Trialists Collaboration, Bonati LH, Dobson J, Algra A, Branchereau A, Chatellier G, Fraedrich G, Mali WP, Zeumer H, Brown MM, Mas JL, Ringleb PA : Shortterm outcome after stenting versus endarterectomy for symptomatic carotid stenosis : a preplanned meta-analysis of individual patient data. Lancet $\quad 376: 1062-1073,2010$.

9) Cremonesi A, Setacci C, Manetti R, de Donato G, Setacci F, Balestra G, Borghesi I, Bianchi P, Castriota F : Carotid angioplasty and stenting : lesion related treatment strategies. Euro Intervention 1 : 289-295, 2005.

10) Eckstein HH, Reiff T, Ringleb P, Jansen O, Mansmann U, Hacke W ; SPACE-2 Investigators: SPACE-2:A missed opportunity to compare carotid endarterectomy, carotid stenting, and best medical treatment in patients with asymptomatic carotid stenoses. Eur J Vasc Endovasc Surg 51 : 761-765, 2016.

11) Egashira Y, Yoshimura S, Sakai N, Enomoto Y ; Japanese Registry of Neuroendovascular Therapy Investigators : Real-world experience of carotid artery stenting in Japan : analysis of 7,134 cases from JR-NET1 and 2 nationwide retrospective multi-center registries. Neurol Med Chir (Tokyo) 54:32-39, 2014.

12) Eliasziw M, Spence JD, Barnett HJ : Carotid endarterectomy does not affect long-term blood pressure : observations from the NASCET. North American Symptomatic Carotid Endarterectomy Trial. Cerebrovasc Dis 8:20-24, 1998.

13) Eliasziw M, Streifler JY, Fox AJ, Hachinski VC, Ferguson GG, Barnett HJ : Significance of plaque ulceration in symptomatic patients with high-grade carotid stenosis. North American Symptomatic Carotid Endarterectomy Trial. Stroke 25 : 304-308, 1994.

14) Fox AJ, Eliasziw M, Rothwell PM, Schmidt MH, Warlow CP, Barnett $\mathrm{HJ}$ : Identification, prognosis, and management of patients with carotid artery near occlusion. AJNR Am J Neuroradiol 26:2086-2094, 2005.

15) Gasecki AP, Eliasziw M, Ferguson GG, Hachinski V, Barnett $\mathrm{HJ}$ : Long-term prognosis and effect of endarterectomy in patients with symptomatic severe carotid stenosis and contralateral carotid stenosis or occlusion: results from NASCET. North American Symptomatic Carotid Endarterectomy Trial (NASCET) Group.J Neurosurg $\quad 83: 778-782$, 1995.

16) Halliday A, Mansfield A, Marro J, Peto C, Peto R, Potter J, Thomas D ; MRC Asymptomatic Carotid Surgery Trial (ACST) Collaborative Group: Prevention of disabling and fatal strokes by successful carotid endarterectomy in patients without recent neurological symptoms : randomised controlled trial. Lancet $363:$ 1491-1502, 2004.

17) Howard VJ, Meschia JF, Lal BK, Turan TN, Roubin GS, Brown RD Jr, Voeks JH, Barrett KM, Demaerschalk BM, Huston J 3rd, Lazar RM, Moore WS, Wadley VG, Chaturvedi S, Moy CS, Chimowitz M, Howard G, Brott TG ; CREST-2 study investigators : Carotid revascularization and medical management for asymptomatic carotid stenosis : Protocol of the CREST-2 clinical trials. Int J Stroke 12: 770-778, 2017.

18) International Carotid Stenting Study Investigators, Ederle J, Dobson J, Featherstone RL, Bonati LH, van der Worp HB, de Borst GJ, Lo TH, Gaines P, Dorman PJ, Macdonald S, Lyrer PA, Hendriks JM, McCollum C, Nederkoorn PJ, Brown MM : Carotid artery stenting compared with endarterectomy in patients with symptomatic carotid stenosis (International Carotid Stenting Study) : an interim analysis of a randomised controlled trial. Lancet $\quad 375: 985^{-997}$, 2010.

19) Kappelle LJ, Eliasziw M, Fox AJ, Sharpe BL, Barnett HJ : Importance of intracranial atherosclerotic disease in patients with symptomatic stenosis of the internal carotid artery. The North American Symptomatic Carotid Endarterectomy Trail. Stroke 30 : 282-286, 1999.

20) Mas JL, Chatellier G, Beyssen B, Branchereau A, Moulin T, Becquemin JP, Larrue V, Lievre M, Leys D, Bonneville JF, Watelet J, Pruvo JP, Albucher JF, Viguier A, Piquet P, Garnier P, Viader F, Touze E, Giroud M, Hosseini H, Pillet JC, Favrole P, Neau JP, Ducrocq X; EVA-3S Investigators : Endarterectomy versus stenting in patients with symptomatic severe carotid stenosis. N Engl J Med $355: 1660^{-}$ 1671, 2006.

21) Miyachi S, Taki W, Sakai N, Nakahara I ; Japanese CAS Survey Investigators : Historical perspective of carotid artery stenting in Japan : analysis of 8,092 cases in The Japanese CAS survey. Acta Neurochir (Wien) 154:2127-2137, 2012.

22) Muller-Hulsbeck S, Schafer PJ, Charalambous N, Schaffner SR, Heller M, Jahnke T : Comparison of carotid stents : an 
in-vitro experiment focusing on stent design. J Endovasc Ther 16:168-177, 2009.

23) North American Symptomatic Carotid Endarterectomy Trial Collaborators, Barnett HJM, Taylor DW, Haynes RB, Sackett DL, Peerless SJ, Ferguson GG, Fox AJ, Rankin RN, Hachinski VC, Wiebers DO, Eliasziw M : Beneficial effect of carotid endarterectomy in symptomatic patients with highgrade carotid stenosis. N Engl J Med 325: 445-453, 1991.

24) Rosenfield K, Matsumura JS, Chaturvedi S, Riles T, Ansel GM, Metzger DC, Wechsler L, Jaff MR, Gray W ; ACT I Investigators : Randomized trial of stent versus surgery for asymptomatic carotid stenosis. N Engl J Med 374: 10111020, 2016.

25) Schneider PA, Levy E, Bacharach JM, Metzger DC, Randall B, Garcia A, Siddiqui A, Schonholz C, Gray W : A first-inhuman evaluation of a novel mesh-covered stent for treatment of carotid stenosis in patients at high risk for endarterectomy : 30-day results of the SCAFFOLD trial. JACC Cardiovasc Interv 11:2396-2404, 2018.

26) Schofer J, Musialek P, Bijuklic K, Kolvenbach R, Trystula M, Siudak $Z$, Sievert $\mathrm{H}:$ A prospective, multicenter study of a novel mesh-covered carotid stent: The CGuard CARENET trial (Carotid Embolic Protection Using MicroNet) : JACC Cardiovasc Interv $\quad 8$ : 1229-1234, 2015.

27) Silver FL, Mackey A, Clark WM, Brooks W, Timaran CH, Chiu D, Goldstein LB, Meschia JF, Ferguson RD, Moore WS, Howard G, Brott TG ; CREST Investigators : Safety of stenting and endarterectomy by symptomatic status in the Carotid Revascularization Endarterectomy Versus Stenting
Trial (CREST). Stroke 42:675-680, 2011.

28) SPACE Collaborative Group, Ringleb PA, Allenberg J, Bruckmann H, Eckstein HH, Fraedrich G, Hartmann M, Hennerici M, Jansen O, Klein G, Kunze A, Marx P, Niederkorn K, Schmiedt W, Solymosi L, Stingele R, Zeumer H, Hacke W : 30 day results from the SPACE trial of stentprotected angioplasty versus carotid endarterectomy in symptomatic patients : a randomised non-inferiority trial. Lancet 368: 1239-1247, 2006.

29) Tietke MW, Kerby T, Alfke K, Riedel C, Rohr A, Jensen U, Zimmermann $\mathrm{P}$, Stingele R, Jansen $\mathrm{O}$ : Complication rate in unprotected carotid artery stenting with closed-cell stents. Neuroradiology 52:611-618, 2010.

30) Tokuda R, Yoshimura S, Uchida K, Yamada K, Satow T, Iihara K, Sakai N ; Japanese Registry of NeuroEndovascular Therapy (JR-NET) investigators : Real-world experience of carotid artery stenting in Japan: Analysis of 8458 cases from the JR-NET3 nationwide retrospective multi-center registries. Neurol Med Chir (Tokyo) 59: 117-125, 2019.

31) Wissgott C, Schmidt W, Behrens P, Brandt C, Schmitz KP, Andresen R: Experimental investigation of modern and established carotid stents. RoFo 186: 157-165, 2014.

32) Yadav JS, Wholey MH, Kuntz RE, Fayad P, Katzen BT, Mishkel GJ, Bajwa TK, Whitlow P, Strickman NE, Jaff MR, Popma JJ, Snead DB, Cutlip DE, Firth BG, Ouriel K ; Stenting, and Angioplasty with Protection in Patients at High Risk for Endarterectomy Investigators : Protected carotidartery stenting versus endarterectomy in high-risk patients. N Engl J Med 351 : 1493-1501, 2004.

㑯動脈ステント留置術（CAS）は, CEA 高危険群のみならす標準危険群に対しても CEA と同等の 治療効果が得られることが示されているが, それぞれの治療における合併症内訳が異なり, 特に CAS における周術期脳卒中の発生, 高齢者に対する成績不良が今後克服すべき問題点として挙げられる. 近年の治療の発展に従い CEA, CAS, 内科治療とも成績が向上してきているが, 周術期塞栓性合併症 を克服するデバイスの洗練化, 新規開発が進むCAS の治療成績に注目していく必要がある. 一方, 無症候性病変, 高齢者への治療介入は慎重に検討しなければならず, 各治療を比較した新たなエビデ ンスの創出が必要な時期に差し掛かっている. 